\title{
Geological Characteristics and Regional Prospecting Model of Wulanchongji Gold Orebody, Alxa Youqi, Inner Mongolia, China
}

\author{
Yonghui Su1,2, Yang Liư ${ }^{3}$, Chao $\mathrm{Li}^{2}$, Shuai Zhao² \\ ${ }^{1}$ School of Earth Sciences and Resources, China University of Geosciences (Beijing), Beijing, China \\ ${ }^{2}$ Inner Mongolia No.1 Geological Mineral Exploration and Development Co., Ltd., Hohhot, Inner Mongolia, China \\ ${ }^{3}$ Erdaojiang Branch of Tonghua Land and Resources Bureau, Tonghua, China \\ Email: syh200@qq.com
}

How to cite this paper: Su, Y.h., Liu, Y., Li, C. and Zhao S. (2021) Geological Characteristics and Regional Prospecting Model of Wulanchongji Gold Orebody, Alxa Youqi, Inner Mongolia, China. International Journal of Geosciences, 12, 431-438.

https://doi.org/10.4236/ijg.2021.124023

Received: March 31, 2021

Accepted: April 27, 2021

Published: April 30, 2021

Copyright $\odot 2021$ by author(s) and Scientific Research Publishing Inc. This work is licensed under the Creative Commons Attribution International License (CC BY 4.0).

http://creativecommons.org/licenses/by/4.0/

\begin{abstract}
Five gold deposits (mineralization) were found in the study area by means of geological mapping, soil geochemical survey and trough exploration engineering. The ore-bearing lithology is mainly metamorphic feldspar sandstone of the Upper Carboniferous Benbatu Formation, and the gold (mineralization) body is controlled by both structural factors and stratigraphic factors of the Upper Carboniferous Benbatu Formation. The genetic type is preliminary concluded to be volcanic hydrothermal type, and the metallogenic age is late Variscan. In this paper, by studying the geological characteristics and metallogenic geological conditions of the gold orebody in the area, a regional prospecting model has been established, which is of great significance to better guide the prospecting work of similar gold deposits in the area and the region.
\end{abstract}

\section{Keywords}

Gold Ore, Hydrothermal Solution, Genesis of Mineral Deposit, Prospecting Model, Benbatu Formation

\section{Introduction}

The research area is located $220 \mathrm{~km}$ northwest of Bayanhot Town, the government seat of Alxa Zuoqi, within the territory of Tamusubraga Town, Alxa Youqi, Inner Mongolia Autonomous Region of China. The study area is located in the Ejinaqi-hinggan mountains proterozoic era, variscan, Yanshanian of $\mathrm{Cu}, \mathrm{Pb}, \mathrm{Zn}$, $\mathrm{Au}, \mathrm{Ag}, \mathrm{Gr}, \mathrm{Nb}$ as a mining area, Wuliji-Xilinhaote proterozoic era, variscan, Yanshanian of $\mathrm{Cu}, \mathrm{Fe}, \mathrm{Gr}, \mathrm{Au}$, Fluorite metallogenic belt [1] [2] [3] [4]. The discovered gold deposits in the vicinity of the study area include Zhulazhaga gold deposit and Chaganchulu gold deposit, which indicate that this area has a good 
gold prospecting prospect [5] [6] [7] [8]. In this paper, by studying the geological characteristics and metallogenic geological conditions of the gold orebody in the area, a regional prospecting model has been established, which is of great significance to better guide the prospecting work of similar gold deposits in the area and the region.

\section{Regional Geological Background}

Regional inland emerging extensive exposure, there are Carboniferous, Cretaceous, Quaternary strata. The area of magmatic rocks is limited, mainly Permian and Triassic intrusive rocks. The region has experienced multiple periods of tectonic superposition, the main direction of the tectonic line is NEE, followed by NWW and nearly EW, and the late superposition of NE and NW, forming a complex tectonic framework.

\subsection{Strata}

The strata in the region are from old to new: Benbatu Formation of Carboniferous Upper Series $\left(\mathrm{C}_{2} b b\right)$, Bayingebi Formation of Cretaceous Lower Series $\left(\mathrm{K}_{1} b\right)$, Wulansuhai Formation of Cretaceous Upper Series $\left(\mathrm{K}_{2} \mathrm{~W}\right)$, Quaternary Upper Pleistocene $\left(\mathrm{Qp}_{3}^{p l}\right)$ and Holocene lake sediments $\left(\mathrm{Qh}^{\top}\right)$, aeolian sand $\left(\mathrm{Qh}^{e o l}\right)$ and diluvial deposits $\left(\mathrm{Qh}^{a}\right)$ [9] [10] [11].

Among them, the Upper Carboniferous Benbatu Formation $\left(\mathrm{C}_{2} b b\right)[11]$ is the oldest strata outcropping in the area, and it is also the strata most closely related to gold mineralization. It is mainly distributed in the central and northern part of the area, with a small amount distributed in the central and western parts and southeast parts. The stratigraphic trend is mainly NEE and NWW. The lithology of the formation is mainly metamorphic sandstone, metamorphic feldspar sandstone, metamorphic feldspar quartz sandstone, intercalated tuff, intercalated crystalline limestone and a few phyllite. Due to the influence of regional dynamic metamorphism, the rocks in this formation are mostly slightly metamorphic, and some of them develop in pieces. The strata of this formation were intruded by Early Permian monzonitic granite in the central and western part of the region, and most of them were unconformably covered by the Wulansuhai Formation of the Upper Cretaceous.

\subsection{Magmatic Rocks}

The regional magmatic rocks are mainly intrusive rocks, followed by volcanic rocks.

The upper intrusive rocks are mainly distributed in the western part of the region in the NNE direction, which is consistent with the general tectonic line direction of the region. There are two mapping units, namely, Early Permian Medium-fine grained monzonitic granite $\left(\mathrm{P}_{1} \eta \gamma\right)$ and Early Triassic diorite porphyrite $\left(\mathrm{T}_{1} \delta \mu\right)$.

Volcanic rocks in this region are pyroclastic rocks, i.e. tuff in the strata of 
Benbatu Formation of Upper Carboniferous Series.

\subsection{Metamorphism}

According to the distribution of metamorphic rocks, the regional tectonic environment and the relationship between the metamorphic rocks and fault structures and magmatic intrusions, the metamorphism in the region can be divided into three types: regional metamorphism, contact metamorphism and dynamic metamorphism. Among them, regional metamorphism is dominant, contact metamorphism and dynamic metamorphism are relatively limited.

The Upper Carboniferous Benbatu Formation was transformed by regional metamorphism, by regional low temperature dynamic metamorphism of low green schist facies in the early stage, and superimposed by dynamic metamorphism and local contact metamorphism in the late stage.

\subsection{Structure}

The upper level tectonic unit belongs to the North China Plate, the second level tectonic unit belongs to the North China continental margin proliferation zone, and the third level tectonic unit belongs to the Baoyintu-Xilinhot volcanic passive continental margin [12].

The oldest strata in the region are the Benbatu Formation of the Carboniferous Upper series. During the Late Carboniferous period, the crust was extended and subsided, and the shallow Marine clastic rocks of the Benbatu Formation were deposited, with calcareous and tuffaceous components. During Late Carboniferous to Triassic, the North China plate and Tarim plate converged, collided and closed, and the magmatic activity occurred regionally. On the basis of inheriting the early tectonic framework, the Mesozoic superimposed the NE and NW trending tectonic activities, which formed a large scale fault basin in and around the region, and deposited the continental sedimentary strata of Bayingebi and Wulansuhai Formations. In short, the region has experienced multiple periods of tectonic superposition, the main direction of the tectonic line is NEE, the second is NWW, near EW, and the late superposition of NE and NW, forming a complex tectonic framework.

\section{Geological Characteristics of Ore (Mineralization) Body}

Through 1:10,000 geological mapping, 1:10,000 soil geochemical survey, 1:5000 comprehensive profile survey of geology, soil, high-precision magnetic and induced polarization middle ladder measurement, trench exploration and other geological exploration means, five gold mineralized bodies (No. 1, 2, 3, 4, 5) have been found in the study area, among which one gold ore body is developed in No. 1 and No. 3 gold mineralized body, with No. 1-1 and No. 3-1 respectively.

\subsection{Characteristics of Mineralized Bodies}

1) Characteristics of No. 1 gold mineralization body and No. 1-1 gold orebody 
No. 1 gold mineralization body is located in the west of WAP1 anomaly and the HSP2 mineralized alteration zone. Controlled by probing trough WTC1. The mineralization body is layered, similar to layered, $4.7 \mathrm{~m}$ wide and $150 \mathrm{~m}$ long. The occurrence is $335^{\circ} \angle 78^{\circ}$. The Au content ranges from 0.13 to $2.17 \mathrm{~g} / \mathrm{t}$, with an average content of $0.74 \mathrm{~g} / \mathrm{t}$. The ore host lithology is limonitized silicified metamorphic feldspar sandstone of the Upper Carboniferous Benbatu Formation, the top and floor wall rocks are metamorphic feldspar sandstone of the Upper Carboniferous Benbatu Formation, and limonitized silicified metamorphic feldspar sandstone can be seen near the ore surrounding rocks.

No. 1-1 gold orebody is located in No. 1 gold mineralization body. It is stratified and like stratified, $1 \mathrm{~m}$ wide and about $150 \mathrm{~m}$ long. The occurrence is $335^{\circ}$ $\angle 78^{\circ}$. The Au content range is $2.17 \mathrm{~g} / \mathrm{t}$. The ore host lithology is limonitized silicified metamorphic feldspar sandstone of the Upper Carboniferous Benbatu Formation, the top and floor wall rocks are metamorphic feldspar sandstone of the Upper Carboniferous Benbatu Formation, and limonitized silicified metamorphic feldspar sandstone can be seen near the ore surrounding rocks.

2) Characteristics of No. 2 gold mineralization body

No. 2 gold mineralization body is located in the west of WAP1 anomaly, the HSP2 mineralization alteration zone, and the south of No. 1 gold mineralization body. Controlled by probing trough WTC1. The mineralization body is stratified and quasi-stratified, $3 \mathrm{~m}$ wide and about $150 \mathrm{~m}$ long. The occurrence is $335^{\circ} \angle$ $68^{\circ}$, and the Au content is $0.12-0.13 \mathrm{~g} / \mathrm{t}$. Ore lithology of carboniferous system on the batu group sericitization limonite silicide metamorphic arkose, roof and base rock of carboniferous system on the batu group metamorphic arkose, near mine roof surrounding rock of carboniferous system on the silicide batu group metamorphic arkose, near mine bottom surrounding rock of carboniferous system on the batu group sericitization chloritization metamorphic feldspar sandstone.

3) Characteristics of No. 3 gold mineralization body and No. 3-1 gold orebody

No. 3 gold mineralization body is located in the west of WAP1 anomaly, the HSP2 mineralization alteration zone, and the south of No. 2 gold mineralization body. Controlled by probing trough WTC1. The mineralized body is stratified and vein-like, $8 \mathrm{~m}$ wide and about $150 \mathrm{~m}$ long, with an occurrence of $340^{\circ} \angle$ $70^{\circ}$, Au content of $0.16-4.68 \mathrm{~g} / \mathrm{t}$, with an average content of $0.92 \mathrm{~g} / \mathrm{t}$. The host rocks are limonitized silicified metamorphic feldspar sandstone and quartz veinlet, the top and floor surrounding rocks are metamorphic feldspar sandstone of the Upper Carboniferous Series Benbatu Formation, and the near ore surrounding rocks are limonitized silicified metamorphic feldspar sandstone of the Upper Carboniferous Series Benbatu Formation.

No. 3-1 gold orebody is located in No. 3 gold mineralization body. It is layered and vein-like, $2 \mathrm{~m}$ wide and about $150 \mathrm{~m}$ long, with an occurrence of $340^{\circ} \angle$ $70^{\circ}$. Au content ranged from 1.4 to $4.68 \mathrm{~g} / \mathrm{t}$, with an average content of $3.04 \mathrm{~g} / \mathrm{t}$. The host rock is the limonitized silicified metamorphic feldspar sandstone of the Upper Carboniferous Series Benbatu Formation, the surrounding rock of the 
roof and floor is the metamorphic feldspar sandstone of the Upper Carboniferous Series, and the surrounding rock is the limonitized silicified metamorphic feldspar sandstone of the Upper Carboniferous Series.

4) Characteristics of No. 4 gold mineralization body

No. 4 gold mineralization body is located in the west of WAP1 anomaly and the HSP2 mineralized alteration zone. Controlled by probing trough WTC2. The mineralization body is stratified, similar to stratified, $2 \mathrm{~m}$ wide, $200 \mathrm{~m}$ long, with an occurrence of $350^{\circ} \angle 40^{\circ}$. Au content is $0.12-0.20 \mathrm{~g} / \mathrm{t}$, the average content is $0.16 \mathrm{~g} / \mathrm{t}$. The host rock is limonitized silicified metamorphic feldspar sandstone of the Upper Carboniferous Benbatu Formation, the top and floor wall rocks are metamorphic feldspar sandstone of the Upper Carboniferous Benbatu Formation, and the near wall rocks are the metamorphic feldspar sandstone of the Upper Carboniferous System.

5) Characteristics of No. 5 gold mineralization body

No. 5 gold mineralization body is located in the west of WAP1 anomaly, the HSP2 mineralization alteration zone, and the south of No. 4 gold mineralization body. Controlled by probing trough WTC2. The mineralization body is stratified, similar to stratified, $8 \mathrm{~m}$ in width and about $200 \mathrm{~m}$ in length. The occurrence is $350^{\circ} \angle 45^{\circ}$. The $\mathrm{Au}$ content ranges from 0.11 to $0.86 \mathrm{~g} / \mathrm{t}$, and the average content is $0.32 \mathrm{~g} / \mathrm{t}$. Ore lithology of carboniferous system on the batu group sericitization limonite silicide metamorphic arkose, roof and base rock of carboniferous system on the batu group metamorphic arkose, roof nearly ore rock of carboniferous system on the batu group sericitization metamorphic arkose, on the floor near ore rock in carboniferous system this batu group of limonite silicide metamorphic feldspar sandstone.

The above gold deposit (mineralization) bodies are controlled by both structural and stratigraphic factors of Benbatu Formation of Carboniferous Upper Series.

\subsection{Genetic Types of Ore Deposits}

The known gold deposits in Inner Mongolia can be divided into 5 major types and 20 deposit subtypes: heavy lava magma hydrothermal gold deposit, metamorphic hydrothermal gold deposit, sedimentary metamorphic hydrothermal gold deposit, volcano-subvolcanic hydrothermal gold deposit, and arenaceous gold deposit [13] [14] [15] [16].

The genetic type of gold deposit in this study area is preliminarily inferred to be volcanic hydrothermal type, and the metallogenic age is late Variscan.

\section{Regional Prospecting Model}

Based on comprehensive analysis of regional metallogenic geological background and metallogenic regularity and comparative analysis of regional important ore sites, it is considered that the metallogenic geological conditions of the gold deposit (mineralization) point in this study area are similar to those of Chagan- 
chulu gold deposit located $18 \mathrm{~km}$ east of the study area, i.e., $10 \mathrm{~km}$ east of Wuliji. Through comparative analysis and combined with the unique metallogenic conditions in this area, the regional volcanic hydrothermal type gold polymetallic ore prospecting model is established (Table 1).

Table 1. Geological prospecting model of volcanic hydrothermal gold polymetallic deposit.

\begin{tabular}{|c|c|}
\hline Model category & Regional reference model \\
\hline $\begin{array}{l}\text { Name of typical deposit } \\
\text { (point) }\end{array}$ & Chaganchulu gold mine [7] [8]. \\
\hline Metallogenic belt & $\begin{array}{l}\text { Grade III metallogenic belt: Wuliji-Xilinhaote proterozoic era, } \\
\text { variscan, Yanshanian of } \mathrm{Cu}, \mathrm{Fe}, \mathrm{Gr}, \mathrm{Au} \text {, Fluorite metallogenic belt. }\end{array}$ \\
\hline Strata & $\begin{array}{l}\text { The strata are metamorphic limestone, pebbled limestone, } \\
\text { conglomerate, breccia, argillaceous SLATE, sericite-quartz SLATE, } \\
\text { quartz sandstone and calcareous sandstone of Amushan formation } \\
\text { of Upper Carboniferous. The ore-bearing geological body is the } \\
\text { subvolcanic rock intruding into the stratum. }\end{array}$ \\
\hline Fracture structure & $\begin{array}{l}\text { The intersection of two groups of secondary faults near SN } \\
\text { direction and NEE direction is the most intense mineralization site }\end{array}$ \\
\hline Magmatic rocks & $\begin{array}{l}\text { The ore-bearing geological bodies occur in the subvolcanic rocks, } \\
\text { and the lithology is cataclastic subdacite. The subvolcanic rock } \\
\text { mass is situated in the upper Carboniferous Amushan Formation } \\
\text { in EW direction. }\end{array}$ \\
\hline
\end{tabular}

Ore source

Main ore-controlling factors

The mineralization of surrounding rock
Stratigraphy of Amushan Formation and volcanic hydrothermal fluid.

Structural and intrusive subvolcanic rocks (cataclastic subdacite) in the amushan formation.

The surrounding rock of the top and floor of the gold mineralized bed is limestone of Amushan Formation and pebbled calcareous sandstone.

The orebody shape

Wall rock alteration

Metallogenic indicator element

Ore mineral association

Gangue mineral

assemblage

Ore grade

Natural type

$0.5-17.32 \mathrm{~g} / \mathrm{t}$

Tectonic altered rock - quartz veinlet type

Genetic type

Volcanic hydrothermal type

Small gold

\section{This study area model}

Wulanchongji gold mine.

Grade III metallogenic belt: Wuliji-Xilinhaote proterozoic era, variscan, Yanshanian of $\mathrm{Cu}, \mathrm{Fe}$, $\mathrm{Gr}, \mathrm{Au}$, Fluorite metallogenic belt.

The host lithology is metamorphic feldspar sandstone, crystalline limestone and phyllite of the Upper Carboniferous Benbatu Formation.

Controlled by NEE trending fracture.

In the surrounding rock far away from the orebody (the surface is $460 \mathrm{~m}$ south of the orebody), there are volcanic clastic rocks of the Benbatu Formation, whose lithology is rhyolitic lithic and dacitic lithic clastic tuff.

It is mainly from Benbatu Formation, and partly from volcanic hydrothermal fluid.

Structure and stratigraphy of Benbatu Formation

The surrounding rocks are metamorphic feldspar sandstone, crystalline limestone and phyllite of the Bemba Tu Formation, while the surrounding rocks in the distance (the surface is $460 \mathrm{~m}$ south of the orebody) are rhyolitic lithic crystal tuff and dacitic lithic crystal tuff.

Lamellar, lamellar, veined, lenticular

Limonitization, silicification, kaolinization, potassification, hematitization, mylonitization.

$\mathrm{Au}$ and As were the main components, followed by $\mathrm{Sb}, \mathrm{Cu}, \mathrm{Ag}, \mathrm{Pb}$ and $\mathrm{Zn}$.

Limonite, natural gold.

Plagioclase, quartz, potassium feldspar.

$0.1-4.68 \mathrm{~g} / \mathrm{t}$

Tectonic altered rock type, gold-bearing quartz veinlet type.

Volcanic hydrothermal type

Gold spot 


\section{Conclusion}

At present, the work level of Wulan Chongji gold deposit is very low. The regional prospecting model established according to its geological characteristics and metallogenic geological conditions will play a positive guiding role in the prospecting work of this study area and similar gold deposits in the region.

\section{Conflicts of Interest}

The authors declare no conflicts of interest regarding the publication of this paper.

\section{References}

[1] Chen, Y.C. (1999) Mineral Resources Prospect Evaluation of Main Metallogenic Belt in China. Geological Publishing House, Beijing, 248-281.

[2] Shao, H.M. and Zhang, L.Q. (2001) Main Metallogenic Belts and Metallogenic Series in Inner Mongolia Autonomous Region. 42-50.

[3] Li, J.J. (2006) Regional Metallogenic System of Alxa Block in Inner Monolia Autonomous Region. Ph.D. Dissertation, China University of Geosciences, Beijing.

[4] Gao, Y., Zhou, Z.H., Zhang, Y.B., et al. (2021) Comparison of Metallogenic Characteristics and Its Significance of $\mathrm{Cu}, \mathrm{Au}, \mathrm{Pb}, \mathrm{Zn}$ and $\mathrm{U}$ in a Cross-Border Area of China, Mongolia and Russia. Geology and Exploration, 57, 0198-0209.

[5] Ding, C.W., Nie, F.J., Jiang, S.H., et al. (2016) Characteristics and Origin of the Zhulazhaga Gold Deposit in Inner Mongolia, China. Ore Geology Reviews, 73, 211-221. https://doi.org/10.1016/j.oregeorev.2015.02.011

[6] Hou, E g., Li, S.L., Jiang, Y.P., et al. (2012) Geological Characteristics of the Zhulazhaga Gold Deposits in Alxa League, Inner Mongolia, China. Advances in Earth Science, 27, 187-190.

[7] Zhang, P., Yan, S.P., Meng, F.H., et al. (2015) Geological Characteristics and Occurrence Characteristics of the Chaganchulu Gold Deposit in Inner Mongolia. $\mathrm{Ge}$ ology and Exploration, 51, 246-252.

[8] Han, F.W., Niu, F. and Meng, F.H. (2014) Discussion on Genesis of Chaganchulu Gold Deposit in Alxa Zuoqi. Science \& Technology Vision, 10, 294-295.

[9] Li, W.G., Li, Q.F. and Jiang, W.D. (1996) The Multiple Stratigraphic Division of the Country [15]. The Inner Mongolia Autonomous Region of Rock Stratum. China University of Geosciences, Wuhan.

[10] Inner Mongolia Geology and Mineral Exploration and Development Bureau (1991) Inner Mongolia Regional Geology. Geological Publishing House, Beijing, 589-609.

[11] Wang, S.J., Xu, Z.Y., Li, C.H., et al. (2020) Evolution of Central-Southern Margin of the Xing-Meng Orogenic Belt in the Late Paleozoic: Evidence from Carboniferous-Permian Sedimentary Formation and Volcanic Rock in Sonid Right Banner, Inner Mongolia. Acta Petrologica Sinica, 36, 2493-2520.

https://doi.org/10.18654/1000-0569/2020.08.13

[12] Shao, J.D., Wang, H., Zhang, M., et al. (2011) Division of Tectonic Units and Its Geological Characteristics in Inner Mongolia. Western Resources, 2, 51-56.

[13] Huang, S.Q. (2005) Genetic Classification of Gold Deposits in Nei Mongol Autonomous Region. Journal of Geology, 20, 43-48.

[14] Li, Y., Xiong, Y.Q., Shao, G.Y., et al. (2019) A Study of Fluid Inclusions from Tugu- 
rige Gold Deposit, Inner Mongolia: Constraint on Ore Genesis. Mineral Deposits, 38, 319-330.

[15] Yang, J.J., Feng, J., Li, P. (2018) Metallogenic Regularity And Prospecting Potential of Ironcopper-Gold-Polymetallic Deposits In Alxa Area, Inner Mongolia. Geology and Resources, 27, 160-165.

[16] Yang, X. (2019) Comparison of Crust Evolution and Gold Deposits Genesis in the Bayan Obo-Alxa League Region, Inner Mongolia. Ph.D. Dissertation, Chinese Academy of Geological Sciences, Beijing. 